\title{
REPRESENTAÇÕES DE JOSÉ GASPAR RODRÍGUEZ DE FRANCIA A PARTIR DO MANUAL DIDÁTICO
}

\author{
REPRESENTATIONS OF JOSÉ GASPAR RODRÍGUEZ DE FRANCIA FROM THE TEACHING \\ MANUAL
}

https://orcid.org/0000-0002-8782-2239 Clovis Antonio Brighent ${ }^{\text {A }}$

${ }^{\text {A }}$ Universidade Federal de Integração Latino-Americana (Unila), Foz do Iguaçu, Paraná, Brasil

Recebido em: 5 jul. 2021 | Aceito em: 29 abr. 2021 Correspondência: Clovis Antonio Brighent (clovisbrichenti@gmail.com)

\section{Resumo}

O artigo se propõe a analisar as representações de José Gaspar Rodríguez de Francia nos "manuais didáticos" de história na rede de ensino do Paraguai. O trabalho objetiva analisar a construção da sua imagem pública através das narrativas históricas em torno da sua pessoa nos manuais didáticos oficiais de história distribuídos pelo Ministério da Educação - (MEC) do Paraguai e em manuais de escolas privadas, manuais dos anos de 2005, 2010, 2016, 2017. Este trabalho se caracteriza como pesquisa qualitativa, tendo como metodologia a ser aplicada a análises em manuais didáticos de história do Paraguai, livros do ensino fundamental e médio.

Palavras-chave: representações; manual didático; José Gaspar Rodríguez de Francia; Paraguai.

\begin{abstract}
The article proposes to analyze the representations of José Gaspar Rodríguez de Francia in the "didactic manuals" of history in the Paraguayan school system. The work aims to analyze the construction of your public image through historical narratives around you in the official textbooks of history distributed by the Ministry of Education - (MEC) of Paraguay and in textbooks of private schools, textbooks of the years 2005, 2010, 2016, 2017. This work is characterized as qualitative research, having as methodology to be applied to analysis in didactic books of history of Paraguay, elementary and high school books.
\end{abstract}

Keywords: representations; didactic manual; José Gaspar Rodríguez de Francia; Paraguay. 


\section{Introdução}

O papel da história como instrumento de análise é compreender os processos fundamentais de mudança que ocorrem ao longo do tempo e do espaço. O historiador é o investigador, aquele que dialoga com as fontes, que as problematiza, que as avalia. A Historiadora Lilian Schwarcz (2019: 223), observa que a "história costuma ser definida como uma disciplina com grande capacidade de "lembrar", mas adverte que "poucos se "lembram", porém, do quanto ela é capaz de "esquecer". Lembrar e esquecer são partes constitutivas de um mesmo processo, são opções historicamente estabelecidas pelos operadores sociais, dentre eles o Estado, que tem um papel importante de selecionar os atos que desejam ser lembrados e transmitidos a fim de manter a ordem por ele estabelecida.

Sabemos que tanto trabalhos historiográficos como os próprios historiadores não possuem neutralidade em suas ações, porque são sujeitos históricos e interagem com os objetos pesquisados, nesse sentido, para Flamarion Cardoso (2012), a consciência e a razão estão presentes tanto no sujeito como no objeto, deve-se ter atenção.

\footnotetext{
Nas ciências humanas e sociais, a consciência e a razão existem tanto no sujeito quanto no objeto, posto que nelas os seres humanos são tanto sujeitos quanto objetos do conhecimento, o que torna a relação sujeito-objeto, bem como a objetividade do conhecimento científico, assuntos problemáticos. Esse ponto, antes invocado com frequência, enfraqueceu-se como critério de distinção ao descobrir-se que, também nas ciências naturais, o sujeito interage com o objeto que pesquisa e o modifica. (CARDOSO, 2012: 01).
}

Imbuídos da consciência de nosso papel enquanto historiadores, buscaremos analisar as representações de José Gaspar Rodríguez de Francia nos "manuais didáticos" de história distribuídos pelo Ministerio de Educación (MEC) do Paraguai e manuais de escolas privadas nos anos de 2005, 2010, 2016, 2017.

José Gaspar Rodríguez de Francia (1776 e 1840), tornou-se um influente político paraguaio entre 1811 a 1840, tendo participado ativamente do processo de independência, e governado o país por três década, figurando na historiografia paraguaia como um grande herói.

Para nossa análise trabalharemos com o conceito de representação, que segundo Santos (2011: 28), é um conceito que pode ter vários sentidos na língua portuguesa. Originário da língua latina, o vocábulo repraesentare significa "tornar presente" ou "apresentar de novo". Para esse autor o conceito se difundiu nos séculos XIII e XIV, quando o papa e os cardeais 
passaram a ser considerados representantes de Cristo e dos apóstolos. Outro exemplo seria o dos juristas medievais que começaram a usar o termo para personificar a vida coletiva.

De acordo com Chartier (2011), o dicionário Furetière, da língua francesa, publicou em 1690 dois sentidos aparentemente contraditórias, para a palavra "representação". A primeira "remete à ideia e à memória os objetos ausentes, e que nos apresenta tais como são" (CHARTIER, 2011: 17). Nesse exemplo o autor concluiu que a representação nos permitiria “ver o 'objeto ausente' (coisa, conceito ou pessoa), substituindo-o por uma 'imagem' capaz de representá-lo adequadamente". Nesse sentido representar, seria fazer conhecer as coisas mediatamente pela "pintura de um objeto", como os enigmas, os emblemas, as fábulas, as alegorias. O segundo sentido é na perspectiva política e jurídica, representar, "é também 'ocupar o lugar de alguém, ter em mãos sua autoridade'. Dali surge a dupla definição dos representantes: 'aquele que representa numa função pública (...), e 'aqueles que são chamados a uma sucessão estando no lugar da pessoa de quem têm o direito"' (CHARTIER, 2011: 17). Trabalharemos nesse artigo com o sentido literal do conceito de "tornar presente" e com a sua relação a memória de coisas ausentes e como essa memória é revisitada.

Aplicaremos o conceito de representação para analisar manuais didáticos utilizados em centros de ensino do Paraguai. O manual didático, como ferramenta pedagógica, é um instrumento carregado de sentidos, concentrando em sua estrutura imagens, símbolos, personagens históricos, políticos, sociais, fazendo jus a assertiva de Gilberto Freyre (apud SCHWARCZ, 2019: 224), que "o passado nunca foi, o passado continua". A estrutura do manual didático presente no espaço escolar serve como meio de difusão na edificação do “imaginário nacional”, o qual contribui para a formação, manutenção e preservação de memórias históricas e identidades sociais nos espaços escolares. As escolas cumprem com uma dimensão social e política fundamental na sociedade e tem como função primeira a escolha dos conteúdos e das práticas críticas/reflexivas no seu currículo, na sua prática pedagógica e ensino aprendizado dos alunos. Há uma prática de escolhas narrativas cronológicas/lineares, enfatizando "grandes heróis", personagens políticos, sociais, em processos factuais, em detrimento de um processo de ensino aprendizagem mais abrangente, crítico, reflexivo e problematizado.

Para Choppin (2004), os manuais didáticos escolares assumem, conjuntamente ou não, múltiplas funções e o estudo histórico destaca que os manuais didáticos exercem quatro funções essenciais variando consideravelmente segundo o ambiente sociocultural, como: à época, a disciplina, os níveis de ensino, os métodos e as formas de utilização. O autor destaca ainda 
quatro funções referenciais: curricular ou pragmática ${ }^{\mathrm{i}}$; instrumental ${ }^{\mathrm{ii}}$; ideológica e cultural ${ }^{\mathrm{iii}}$; e, documental ${ }^{\mathrm{iv}}$.

Colocamos como elementos central desse artigo compreender como a influência de José Gaspar Rodríguez de Francia foi edificada ao longo do tempo e, analisar a preservação da memória histórica na construção da identidade social no tempo presente a partir do manual didático. Os manuais didáticos serão cotejados com a análises bibliográficas que trata sobre o governo e o personagem de José Gaspar Rodríguez de Francia. Apresentaremos algumas narrativas históricas do período francista, relacionando-as com as narrativas contidas nos manuais didáticos as quais se aproximam e se estruturam cronologicamente.

Nosso estudo coaduna-se com as novas perspectivas da história, como a ampliação das fontes e o papel da história na relação com as novas possibilidades de abordagens e perspectivas que surgiram especialmente com o terceiro período da escola dos Annales, quando ocorreu uma ruptura com a noção historicista tradicional de um tempo uniforme em progressão linear, em favor de temporalidades múltiplas.

Acontecimentos, pessoas, estruturas e processos do passado podem ser objetos de qualquer disciplina humana ou social e, às vezes, até mesmo de uma ciência natural. Tais elementos podem ser estudados historicamente porque pertencem ao passado, mas não é isso, porém, o que os torna históricos. Tornam-se históricos unicamente na medida em que forem representados como tema de um tipo especificamente histórico de escrita. (CARDOSO, 2012: 13).

Pelo poder do Estado em aplicar ao ensino uma narrativa que lhe convenha, de exaltação de figuras míticas, fatos e personagens para enaltecer e dar sentido ao próprio conceito de nação, o manual didático de história pode se converte em um "instrumento" de propagação de narrativas nacionais, de heróis, mártires, os quais são edificados de acordo com determinada conjuntura política e social, de determinado grupo que se destaca ou se alternam em espaços de poder governamental ao longo do tempo e espaço.

\section{Fundamentação teórica: currículo, artefato}

O espaço ensino-aprendizagem é a base da educação escolar moderna ancorada em instituições escolares não neutras, mas que respondem a demandas da sociedade que as mantém. Por seu turno, o currículo e o manual didático são ferramentas maleáveis, modificadas de tempos em tempos, que se transformam e se moldam, para dar sentido e coerência ao ensinoaprendizagem.

Ivor Goodson (1997), que tem dedicado estudos a fim de analisar o papel que o currículo desempenha e as mudanças que ocorreram nas décadas sessenta e setenta, defende que o 
currículo não é neutro e, dada a conjuntura, os interesses daqueles que estão no poder prevalecem em relação à estrutura do currículo. Para o autor, é importante que a história do currículo nos ajude a ver o conhecimento escolar como um artefato social e histórico sujeito a mudanças e flutuações, e não como uma realidade fixa e atemporal. A história do currículo deve estar centrada em uma epistemologia social do conhecimento escolar, preocupada com os determinantes sociais e políticos do conhecimento educacionalmente organizado.

Uma análise historiográfica do currículo, para Tadeu Tomaz da Silva (Apud GOODSON, 1997), não deve se deter na preocupação epistemológica com a "verdade ou validade do conhecimento", nem ter cunho celebratório ou evolucionista e fugir das tentações de uma historiografia tradicional de exaltar "grandes" educadores e pedagogos. Argumenta que:

uma história do currículo tem que ser uma história social do currículo, centrada numa epistemologia social do conhecimento escolar, preocupada com os determinantes sociais e políticos do conhecimento educacionalmente organizado. Uma história do currículo, enfim, não pode deixar de tentar descobrir quais conhecimentos, valores e habilidades eram considerados como verdadeiros e legítimos numa determinada época, assim como não pode deixar de tentar determinar de que forma essa validade e legitimidade foram estabelecidas. (SILVA Apud GOODSON, 1997: 9).

O currículo cumpre uma função social, segundo Goodson (1997), porque ele é concebido para produzir ações nos sujeitos transcende o ambiente escolar e passa a afetar a inclusão/exclusão de pessoas e auferir validade a certos grupos ou certas ideias. Ele, portanto, não é neutro, da mesma forma que a escola como instituição, onde se aplica o currículo na teoria e prática, não é neutra, e nas sociedades modernas exerce influência direta na formação e no sentido atribuído ao mundo do trabalho. Na educação formal, educadores e educandos vivem diretamente os resultados, geralmente conflituosos, da implantação de políticas educacionais formuladas de acordo com as novas demandas criadas pelas mudanças no mundo do trabalho. (AVILA 2016-1018: 1). Assim, entende-se que há uma estreita vinculação do currículo com o conceito de trabalho, no caso aqui das sociedades ocidentais que concebem o trabalho como elementos primordial da existência humana, diferentemente de sociedades originárias da américa que possuem outros conceitos de trabalho. Porém, quando submetidos a força curricular, são levadas a sem moldar aos fundamentos sociais da sociedade ocidental.

As escolas não são instituições isolados, analisa Michael Apple (2006: 102), ao contrário, elas estão conectadas a outras instituições, definidas pelo autor de "poderosas", mas que esse poder é "frequentemente oculto e complexo". Nesse sentido, ocorre uma junção entre escola e currículo, fazendo com o manual didático através de seus conteúdos, imagens, símbolos, narrativas históricas não seja neutro, mesmo entendendo que não existe neutralidade 
independentemente da posição política/pedagógica. Porém, essa não neutralidade, assegura Apple (2006), implica que o conhecimento que chegava e chega as escolas não é aleatório e sim previamente definido, selecionado e relacionado com o sentido que o Estado deseja a escola.

\begin{abstract}
Como tem sido dito repetidamente aqui, o conhecimento que chegava às escolas no passado e que chega hoje não é aleatório. É selecionado e organizado ao redor de um conjunto de princípios e valores que vem de algum lugar, que representam determinadas visões de normalidade e desvio, de bem e de mal, e da 'forma como as boas pessoas devem agir'. Assim para entendermos porque o conhecimento pertencente a apenas determinados grupos tem sido representado em primeiro plano nas escolas, precisamos conhecer os interesses sociais que frequentemente guiaram a seleção do currículo e sua organização. (APPLE, 2006: 104).
\end{abstract}

Nota-se que Goodson (1997) e Aplle (2006) defendem que o currículo não é neutro, para entendê-lo seria preciso entender quais os interesses de determinados grupos sociais que guiam a seleção e organização do currículo, que grupos se encontram no poder de um estado e em suas instituições tendo em vista seus interesses e objetivos quando se trata da educação.

O currículo constitui hoje alvo privilegiado da atenção de autoridades, políticos, professores e especialistas adverte Antonio Moreira (1997). O autor trata o currículo como um instrumento utilizado por diferentes sociedades, direcionado a socialização dos conhecimentos historicamente acumulados e que é utilizado "tanto para desenvolver os processos de conservação, transformação e renovação dos conhecimentos historicamente acumulados como para socializar as crianças e os jovens segundo valores tidos como desejáveis". (MOREIRA, 1997: 11).

O manual didático se transformou em parte constitutiva do contexto curricular, mesmo que para alguns profissionais da área da educação ele sirva apenas como facilitador no processo de ensino aprendizagem, ele é uma "ferramenta" que se une a prática pedagógica. Para o historiador filosofo alemão Jörn Rüsen (1997), o livro didático vai além de ser um facilitador da prática pedagógica dos profissionais da educação.

Todos los expertos están de acuerdo en que el libro de texto es la herramienta más importante en la enseñanza de la historia. Por eso recibe una amplia atención incluso por parte de aquellos que se interesan por la enseñanza de la historia en la escuela y su significado para la cultura política. Para que el Ministerio de cultura conceda su aprobación a los libros de texto, se han puesto en marcha distintos procesos de inspección y autorización en los que se discute vivamente qué cualidades debe tener un libro de texto. (RÜSEN, 1997: 79).

Evidentemente que não podemos considerar o manual didático o protagonista no ensino de história, é necessário considerar que existe um contexto carregado de significados que levam para uma proximidade ao longo do tempo e espaço, aproximando ou edificando os sujeitos 
históricos do passado e do presente a interesses que se ligam à cultura política e que perpassa pela cultura escolar. Isso implica reconhecer o indivíduo como sujeito histórico do seu tempo, ao mesmo tempo que é um sujeito político, suas relações sociais cotidianamente são relações que passam pela política. A consciência histórica dos estudantes, ou seja, aquele conhecimento, experiências e vivências acumuladas como sujeitos históricos, junto com o manual didático, é peça chave para o processo de ensino-aprendizagem de história.

La consciencia histórica es el mismo tiempo el ámbito y el objetivo del aprendizaje histórico. Se pueden describir sus operaciones mentales más importantes, y también se pueden tomar en consideración sus funciones en la vida práctica antes que todas las divergencias políticas que se pueden argumentar sobre el alcance y la dirección de su realización y, en este sentido, también se puede razonar con argumentos válidos y un amplio consenso lo que debería saber el alumnado para considerar que ha conseguido con éxito un aprendizaje histórico satisfactorio. En pocas palabras, la consciencia histórica se puede describir como la actividad mental de la memoria histórica, que tiene su representación en una interpretación de la experiencia del pasado encaminada a poder comprender las actuales condiciones de vida y a desarrollar perspectivas de futuro de la práctica vital conforme a la experiencia. (RUSEN, 1997: 81).

O pesquisador considera a consciência histórica como a atividade mental da memória histórica, que tem sua representação em uma interpretação das experiências passada, com o objetivo de entender as condições de vida atuais e desenvolver perspectivas futuras da prática vital de acordo com a experiência. Nesse sentido, entende-se que a estrutura do manual didático, suas imagens, narrativas históricas, tempos, cronologia, personagens, heróis, mitos, símbolos, tem função não apenas de despertar o conhecimento como de ativar a consciência histórica e também preservar as memórias do passado, moldar e construir identidades desde tenra idade do sujeito como aluno nos espaços escolares os quais os "ritos" se iniciam desde as séries primarias.

No entanto, para além dessas categorias, Skinner (2000) afirma que as obras de arte, literarias e filosóficas "eran objetos intencionales, y en que comprender-los significaba comprender los propósitos que sus autores habían tenido al producirlos, lo que volvía a la tarea del historiador del arte o de las ideas una tarea hermenéutica de primer orden". (SKINNER, 2000: 11).

Nas palavras de Skinner (2000), é possível entender o manual didático como uma obra literária, composto por narrativas históricas, imagens, símbolos, carregados de intencionalidades as quais são confeccionadas para educação. Contudo, o autor interpreta que 
os manuais didáticos correspondem também ao oficio do historiador, buscando compreender o próprio contexto em que um manual foi escrito e confeccionado.

É preciso levar em consideração que um manual didático elaborado e aprovado a pedido de um Estado Nacional especifico ou por uma Instituição de Ensino especifica, remete também aos interesses daqueles que representam esse Estado ou Instituição, o poder político do grupo especifico que lidera o governo de uma Nação ou de um grupo privado a frente de uma instituição de ensino. Nesse sentido, não se pode desconsiderar os interesses subjacentes nos seus conteúdos.

\section{Representações de José Gaspar Rodriguez de Francia segundo a historiografia paraguaia}

A historiografia paraguaia é no geral generosa com José Gaspar Rodriguez de Francia, ele tem espaço garantido e destacada nos manuais didáticos, devido a sua atuação por mais de 30 anos no processo histórico e político do Paraguai do século XIX, período que incorporada a independência (1811) e os primeiros anos de governo. Na narrativa de exaltação, destaca-se o “Compendio de História Paraguaya" de Júlio César Chaves (2010), como um exemplo de narrativa histórica cronologicamente linear, modelo frequentemente observado em trabalhos historiográficos no caso do Paraguai e que se observa nos manuais didáticos.

Francia aparece principalmente a partir dos eventos relacionados ao processo de independência tanto da coroa espanhola quanto do governo de Buenos Aires. Na política, Francia aparece desde a formação do governo provisório. Segundo Chaves (2010: 120), “el 16 de mayo se constituyó el gobierno provisorio, el Cuartel designó como diputados adjuntos para que gobernasen con Velasco al Dr. Francia y al capitán Juan Beleriano de Zevallos, español partidario de los patriotas".

O Paraguai se aclamaria um país independente a partir de 1811, no primeiro Congresso realizado 17 de junho do mesmo ano. Com a queda de Velasco, que anteriormente era governador da província, e a necessidade de organizar nova liderança, optou-se pela formação de uma Junta Superior Governativa para administração do governo, com Francia presente.

Como representantes do governo foram empossados então como presidente: Tenente Coronel Fulgêncio Yegros; como vocales v: José Gaspar Rodríguez de Francia, o Capitão Pedro Juan Caballeiro, o presbítero Francisco Xavier Bogarín e Fenando de La Mora. Assim narra Chaves (2010) sobre a formação dessa junta:

Reiniciada la sesión al día siguiente el representante del partido de los patriotas, Mariano Antonia Molas propuso: 1) que Velasco por los motivos expuestos en el bando del 9 de junio y por haber abandonado el ejército en Paraguarí, quede privado 
de todo mando, subrogándose en su lugar una junta compuesta como presidente por el coronel Fulgencio Yegros, y como vocales el Dr. José Gaspar Rodriguez de Francia, el capitán Pedro Juan Cavallero, el presbítero Francisco Xavier Bogarín y don Fernando de la Mora. (CHAVES, 2010: 121-122).

Parte da historiografia paraguaia, em geral aquela associada a perspectiva positivista da História, e por conseguinte exerce maior influência na produção de material didático ofertado pelo Estado, considera que Francia era a figura civil da época mais talentoso, perspicaz e honrado. Essa narrativa é vista frequentemente em trabalhos históricos dando ênfase a Francia como aquela pessoa que seria a melhor preparada, capacitada para estar presente fazendo parte do Governo. Essa narrativa pode estar associada a sua formação acadêmica, pois ele havia estudado e se formado em Teologia na Universidade de Córdoba em Tucuman, Argentina. Conhecedor de Rousseau, admirava Voltaire, atuava na área do direito e era conhecedor da administração dos Cabildos ${ }^{\mathrm{vi}}$. Além disso, também era visto como bom orador e político.

Um fato que denota sua importância no meio político e no governo, ocorre quando da sua renúncia ocasionada por não concordar com algumas posturas e atitudes dos companheiros da junta governativa. Francia se retira para sua casa localizada nas redondezas de Assunção, e seus companheiros pedem que volte a fazer parte do governo. Chaves (2010) destaca:

\footnotetext{
Estaba ganando impulso en todo el país y el movimiento pro-ternero para el gobierno del Dr. Francia. No vivía en el Consejo capaz de reemplazarlo. [...] Dr. Francia de Ibiraí en el cese de su campaña de autopromoción y en el descrédito de sus antiguos camaradas en el mundo, sin querer exaltar a los pobres del pueblo. También fue decisivo en la crisis debido a la falta de ambición de Fulgencio Yegros y Pedro Juan Cavallero. Ambos preguntaron al ausente. (CHAVES, 2010: 126).
}

Chaves (2010) informa ainda que Francia tinha conhecimento e sabia da importância tanto da preservação da independência como da administração do país. Observava que seus companheiros, em questões pertinentes ao governo, tomavam decisões equivocadas e não sabiam de fato governar, pois estes entendiam mais das questões militares do que das burocracias e medidas que deveriam ser tomadas para o bem da administração do país.

Tudo isso somado à falta de ambição pelo poder de seus companheiros Fulgêncio Yegros e Pedro Juan Cavallero, que não imaginavam o que o futuro destinava para ambos quando Francia se consolidasse sozinho no poder como ditador perpétuo da República.

O político Francia tinha conhecimento do governo e era bom estrategista, na sua volta como membro da junta no governo, uma de suas reivindicações foi a criação de um segundo batalhão de infantaria que ficasse subordinado a sua pessoa a suas ordens sendo o mesmo o próprio comandante. Sabia que tinha que contrabalancear as forças com seus companheiros que 
eram militares e agiam com medidas austeras e desproporcionais contra a população, Francia não concordava com tais atitudes. Assim registra Chaves (2010).

\begin{abstract}
Mas no volvió solo e indefenso, sujeto al capricho de los oficiales del cuartel. Por disposición expresa se creó un segundo batallón de infantería, del cual será comandante "el mencionado vocal-decano Doctor Francia..." Él correrá con su arreglo, disciplina y régimen, y sin su consentimiento no se podrá disponer, dar destino, ni disolver el batallón. Reciba también "la mitad de las municiones existentes en los parques o almacenes. (CHAVES, 2010: 126).
\end{abstract}

Um dos primeiros integrantes a ser afastado politicamente da junta governativa foi Fernando de La Mora em meados de 1813, teria sido acusado por Francia de perder um documento contendo o artigo adicional do tratado de 12 de outubro e de levar uma conduta pouco digna na vida privada. Essa atitude demonstrou que Francia tinha força política suficiente a ponto de influenciar a saída da junta governativa de Fernando de La Mora, o qual era visto como um rival, sendo afastado ficaria livre no governo. Chaves (2010), afirma que mesmo com o documento extraviado encontrado em seguida, a saída de Fernando de La Mora do governo foi efetivada.

A mediados de 1813 fue separado de su cargo de vocal de la Junta, Fernando de La Mora. El doctor Francia le acusó de la pérdida del documento con el artículo adicional al tratado del 12 de octubre y de llevar una conducta poco digna en la vida privada. Aunque el documento extraviado fue encontrado más tarde, la separación se hizo efectiva. Francia quedó entonces libre de todo rival en el gobierno. (CHAVES, 2010: 127).

Após um período de governo houve a dissolução da junta governativa e outro modelo denominado de Consulado foi estabelecido com Francia e Yegros como representantes, sendo que a cada quatro meses se alternariam aquele que ficaria à frente do governo. Cada qual teria um batalhão do exército que ficaria subordinado a sua pessoa, como Yegros que era militar já estava com batalhão formado, Francia formaria o seu, escalando sobre seu mando aqueles que fariam parte desse batalhão, armas e munições seriam divididas entre ambos os lados. $\mathrm{O}$ objetivo desse novo governo era a "conservación, seguridad y defensa de la República con toda la vigilancia, esmero y actividad que exigen las presentes circunstancias". (CHAVES, 2010: 130).

Em certo sentido, observa que a existência de dois batalhões subordinados aos Cónsules, Yegros e Francia, seria a forma mais sensata de balancear as forças em caso de desavenças no governo, do mesmo modo nota-se que Francia tinha consciência da importância que era ter um exército subordinado ao seu mando para o bom andamento tanto administrativamente, como para defesa da Independência da República que era recente e como na preservação das fronteiras, ou casos de insurgências. 
Ambos Cónsules quedaban investidos de la comandancia general de armas que debían ejercer unida y solidariamente, El efectivo del ejército, así como el armamento mayor y menor, municiones de toda especie, tenían que distribuir-se por mitades. Cada Cónsul tendría su batallón de infantería y sus compañías de artillería y un parque o almacén de guerra. Yegros se hacía cargo del batallón existente y Francia quedaba autorizado para levantar sin demora el suyo. A los dos se les confirió la graduación y honores de brigadieres del ejército y el mismo congreso otorgó los despachos respectivos. (CHAVES, 2010: 130).

Após as alternâncias entre Francia e Yegros à frente da administração do governo, Yegros se retira em meados de fevereiro de 1814 e pede a Francia que fique à frente da presidência, enquanto Yegros cuidaria daquilo pertinente ao exército pois era essa sua especialidade, e claro segundo algumas fontes, demonstrava gostar de aproveitar as coisas comuns da vida como festas, bebedeiras.

Com as relações de comércio interrompidas na Região do Prata no período, Yegros defendia uma aproximação com o Brasil a qual Francia era contrário, pois o mesmo tinha um projeto de isolamento chegando a afirmar que "en el Brasil abundaba todo lo que produce en Paraguay y no precisaba de ello" (CHAVES, 2010: 132).

O ambiente criado com a nova composição era vantajoso para Francia, pois Yegros se ocupando da carreira militar, deixava Francia mais à vontade, o qual aproveita para desempenhar com uma intensa atividade administrativa e política, enquanto seu companheiro participava de constantes festas.

El 15 de junio entró el Dr. Francia a ejercer el último turno, desempeñando una intensa actividad administrativa y política, mientras su compañero asistía a constantes fiestas. Al aproximarse la fecha del nuevo congreso comenzó una campaña política preparando "un cambio de sistema gubernativo con un solo magistrado que rigiese los destinos de la República". [...] Su intensa y bien dirigida propaganda había encarnado en el alma nacional la idea de que era él, el sostenedor de la independencia y el salvador de la patria. (CHAVES, 2010: 132).

É possível concluir que Francia se transformaria na pessoa mais apta entre os pares para assumir o poder e governar o país, já Yegros é apresentado como um militar com pouco interesse pela parte burocrática e política da administração, sem falar no modo como vivia festejando, enquanto Francia é apresentado como aquele mais consciente da conjuntura que a jovem República atravessava, almejando também aplicar um sistema de governo onde apenas um magistrado administra-se o país.

Francia é auto aclamado durante as propagandas políticas que fazia para a população e seus pares que o apoiavam como sendo aquele que sustentaria a independência como "salvador da pátria”, discurso nacionalista em certo sentido que levará a apontá-lo e consagrá-lo futuramente como o pai da pátria paraguaia. 
Com o apoio de deputados na nova assembleia, observava-se dois tipos de discurso, um direcionado para Fulgencio Yegros 'como buen militar' e outro para o Consul civil Francia, como aquele salvador da independência e bom administrador, vindo o seu nome a ser eleito em assembleia como ditador da primeira Republica do Sul.

\begin{abstract}
Volvió a usar la palabra Molas reconociendo los méritos de Fulgencio Yegros "como buen militar", más destaco los del Cónsul civil como salvador de la independencia y buen administrador. Agregó que por ello votaría por su dictadura e invitó a todo "buen paraguayo" a hacer lo mismo. Un diputado por la capital pidió la palabra para refutarle, pero otro de la campaña gritó: "Hay que dejarse de tantos discursos y proceder a votarlo a Caraí Francia". Esta interrupción fue aplaudida. Cerró el debate el representante de Concepción José Miguel Ibáñez pidiendo que Francia fuese elegido dictador de la primera República del Sur. Efectuada la votación su nombre fue consagrado por mayoría apreciable. (CHAVES, 2010: 133).
\end{abstract}

Francia teria sido eleito como ditador temporal previsto para terminar o governo em 1817, porém, antes de finalizar a ditadura temporal, em primeiro de junho de 1815, o Congresso se reuniu na Catedral de Assunção para votação de novos mandatos, com baixa participação, contando com apenas 150 deputados dos 300 a 1.000 mil que participavam rotineiramente. Mesmo com alguma oposição o Congresso resolveu eleger Francia como ditador perpétuo da República. Observa-se que o espírito "democrático" na jovem república paraguaia estava se enfraquecendo.

Conforme con lo prescripto por el reglamento de 1813 se reunió el Congreso el 30 de mayo. El período de la dictadura temporal finalizaba em 1817 pero el doctor Francia marchó sin demora al gobierno absoluto y perpetuo. [...] El Congreso resolvió: establecer al Dr. Francia como dictador perpetuo de la Republica 'con calidad de ser sin ejemplar'. El Congreso se reuniría en adelante 'cada vez y cuando el Dictador lo halle necesario'. (CHAVEZ, 2010: 136).

A historiografia paraguaia mais crítica e avessa a corrente positivista descreve Francia como um político tirano, cruel, sanguinário, caracterizando seu período de governo como reino de terror.

Inclusive após se afirmar no poder como ditador perpétuo a partir de 1816, Francia sofre uma tentativa de conspiração em 1820, fato que talvez tenha ajudado a fomentar também uma visão negativa de sua imagem. Essa conspiração fora descoberta quando um dos conspiradores que havia sido aliciado a participar, em busca de se confessar, vai ao encontro de um clérigo em Assunção e o mesmo lhe orienta a delatar o plano da conspiração.

Ao saber da pretensa conspiração Francia toma atitudes rigorosas, severas, manda prender os envolvidos. Ao todo mais de cem pessoas são presas, entre os envolvidos se encontrava o Tenente Coronel Fulgencio Yegros, o qual seria fuzilado posteriormente a mando de Francia e também o Capitão Pedro Juan Caballeiro que seria preso e tiraria a própria vida 
dentro da prisão, ambos participaram do governo ao lado de Francia, eram próceres da independência, porém não foram poupados.

Na historiografia Francia é visto de diversas maneiras, ora mocinho, as vezes cruel, difícil de ser explicado, porém ainda na atualidade o fenômeno Francia continua sendo um caso ímpar, singular, único na América do Sul. Para Carreras (1992 a interpretação tradicional sobre a origem do termo "reino de terror", dirigida ao período de governo de Francia, teria sido pronunciado pelos irmãos Robertson, europeus que teriam vivido por um período no Paraguai do século XIX. "La interpretación tradicional, y sin duda la más conocida, ve en el Dr. Francia a un tirano sangrento que mantuvo a su país aislado y sometido a un régimen despótico calificado como "Reino del Terror", expresión, acuñada por los Hermanos Robertson (1839)". (CARRERAS, 1992: 17).

Carreras analisa ainda que existe um esforço feito pelos historiadores do século XX para tentar explicar o fenômeno Francia com várias abordagens e perspectivas antagônicas. Günter Kahle (1962), em sua tese, aborda Francia como aquele que teve um papel preponderante no processo de formação da consciência nacional paraguaia. Já para Richard White (1978), Francia teria implantado um projeto revolucionário autônomo e popular. Por seu turno, Júlio Cesar Chaves (1964), faz um esforço a partir de diversas análises documentais a fim de buscar manter determinada imparcialidade no seu trabalho, mas com estilo positivista não consegue esconder sua simpatia pela aristocracia assuncionenha.

Entre outros autores historiadores e sociólogos destaca-se Edward Lucas White (1996), que fez de Francia protagonista de uma novela editada nos Estados Unidos; o poeta Pablo Neruda (1970), dedicou um poema que situa Francia como um dos traidores e executores da América Latina. Augusto Roa Bastos (1974), deu fama universal com sua novela denominada de "Yo el Supremo", surgindo com esta obra discursões entre os críticos literários, até que ponto poderia ser atribuído um caráter de ditador ou não ao protagonista.

Segundo Carreras (1992), a visão negativa sobre Francia aparece muito por causa dos seus rivais que fez em sua trajetória de vida tanto no Paraguai como em Buenos Aires a época, principalmente a obra de Mariano Molas (1868), Bartolomé Mitre (1858), e a obra de Domingos F. Sarmiento (1977). Foram os autores do século XX como Cecilio Báez (1910) e Efraím Cardozo (1949), que abriram caminho para uma nova interpretação de um Paraguai isolado por Francia diante da conjuntura que se encontrava o país na região. Já Juan P. Benitez (1937), tratou de buscar as bases sócio-políticas que fizeram possível a sustentação da ditadura. 
Para John H. Williams (1979), Francia buscava construir uma sociedade igualitária, destaca a destruição econômica, política e social da elite, a manutenção da segurança nacional em relação as ameaças exteriores como de indígenas, diversidade na produção e sobretudo a própria criação de uma nação. Dieter Senghaas (1977) e Frieder Schmelz (1981), concordam que Francia manteve um modelo de desenvolvimento autocentrado, chegando à conclusão que este teria sido o único caso aplicado na história da América Latina.

Popularmente no Paraguai seu governo é conhecido por ter realizado uma reforma agrária de caráter radical, diversidade na produção promovida pelo governo por motivo de seu isolamento, controle estatal do comércio exterior e da economia em geral voltada aos interesses da população.

\section{Representações de José Gaspar Rodriguez de Francia nos manuais didáticos de história no} Paraguai

Para o referido artigo analisaremos quatro manuais didáticos para escolas públicas: $\mathrm{O}$ primeiro destinado a oitava série do ensino fundamental: MOREIRA, María Graciela Monte de Lopez, ROMERO, Ana Carolina Reyes, DÁVALOS, Juana. Historia y Geografía. 8. Ministerio de Educación y Cultura - MEC, Viceministerio de Educación. Editorial Don Bosco: Asunción, 2005; o segundo destinado ao ensino médio: EQUIPO EDIOTIAL. história y geografia. Segundo Curso. - Equipo Editorial. - Asunción: Editorial Atlas, 2017.

Na sequência analisaremos duas obras destinadas as escolas privadas, destinadas ao segundo e terceiro anos do ensino médio: IBÁNEZ, Felisa. História y Geografia. Recursos Facilitadores de Enseñanza - Aprendizaje, Con Capacidades, Indicadores y Test de Evaluación. Editora Book Sellers. Nemby - Paraguay. 2016; IBÁNEZ, Felisa. Historia y Geografía. Recursos Facilitadores de Enseñanza - Aprendizaje, Con Capacidades, Indicadores y Test de Evaluación. Editora Book Sellers. Nemby - Paraguay. 2010. Notemos que toda as obras foram publicadas no século XXI.

O manual didático de história e geografia direcionado a $8^{\circ}$ série, confeccionado no ano de 2005, fornecido pelo MEC, reproduz a narrativa cronológica e enaltecedora da figura de Francia. Curiosamente para essa obra a história do Paraguai tem início em 1811, quando o Estado paraguaio passaria por um breve governo provisório, com a instituição de uma Junta Superior Governativa. Posteriormente, outro período de governo o qual foi denominado de Consulado e finalmente um governo denominado Republicano Ditatorial ou Ditadura Temporal e por último Ditadura Perpétua. 
O nome de Francia é destacado com maior proeminência a partir do governo provisório em 1811, com destaque para algumas de suas ações como a destituição de Fernando de La Mora do governo, sua ênfase na elaboração do primeiro documento do Paraguai Independente denominado de 'El Reglamento de Gobierno de 1813' (MOREIRA, ROMERO, DÁVALOS, 2005: 124).

Observa-se que o manual apresenta em suas narrativas as ações de Francia de forma cronológica durante todos os períodos e formas de governo. Apresenta Francia como aquela pessoa que parece ser o mais apto a representar o governo paraguaio. Observação destacada acima, possivelmente considerada pela formação de Francia onde o mesmo estudou em Córdoba, atuava como advogado e conhecia das questões ligadas ao "Cabildo".

El 3 de octubre de 1814 abrió sus sesiones el tercer Congreso presidido por el doctor Francia, quien aconsejó el gobierno unipersonal para la mejor defensa de la república". [...] "Se pensó que solamente un hombre de su carácter y talento sería capaz de afrontar la grave situación ocasionada por la ruptura político-económica con Buenos Aires. (MOREIRA, ROMERO, DÁVALOS, 2005: 125).

O manual didático apresenta em sua estrutura um "mapa mental” (figura 01) direcionado para facilitação da didática do professor e assimilação do aluno e assim poder recordar os períodos de governo em que Francia se encontra em todas as fases de governo, sempre estruturado cronologicamente.

Figura - 1: quadro cronológico, "para recordar".

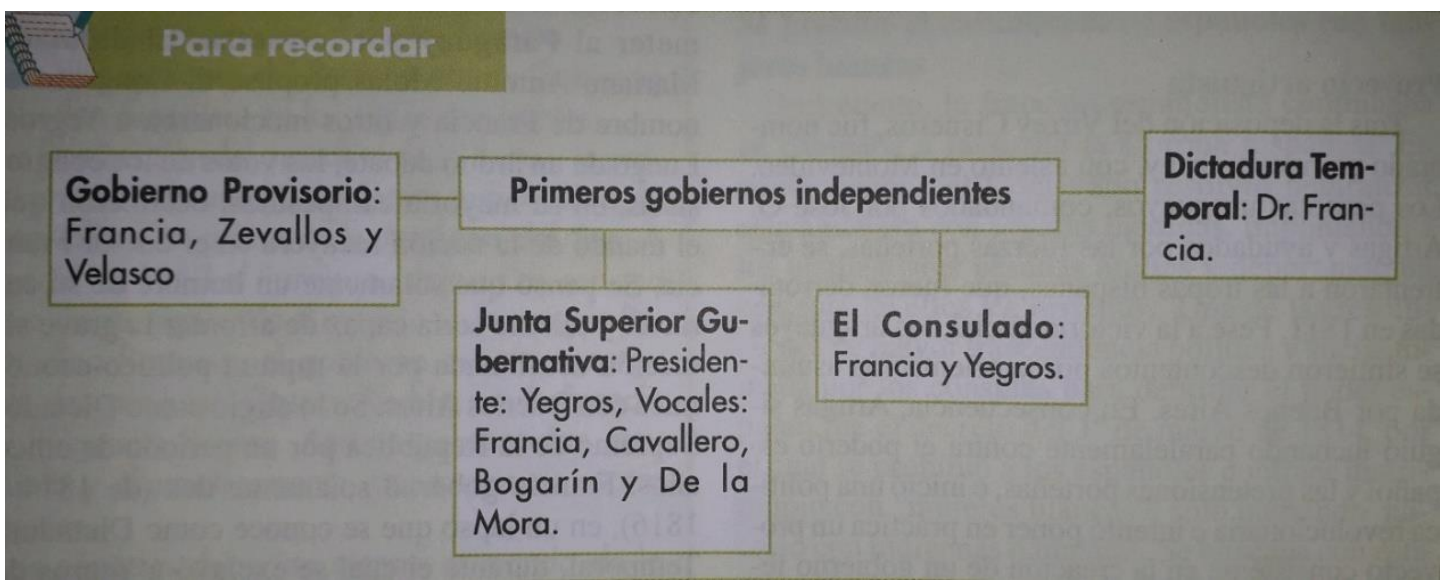

Fonte: MOREIRA, ROMERO, DÁVALOS, 2005: 126.

A estrutura do quadro cronológico acima, contida no manual serve de suporte ao professor na facilitação da prática pedagógica e didática no contexto do ensino aprendizado bem como voltado para certa facilitação da assimilação e, ou memorização do aluno. 
Figura - 2: La Junta Superior Gubernativa: General Fulgencio Yegros, Capitán Pedro Juan Cavallero, Dr. José Gaspar Rodriguez de Francia.

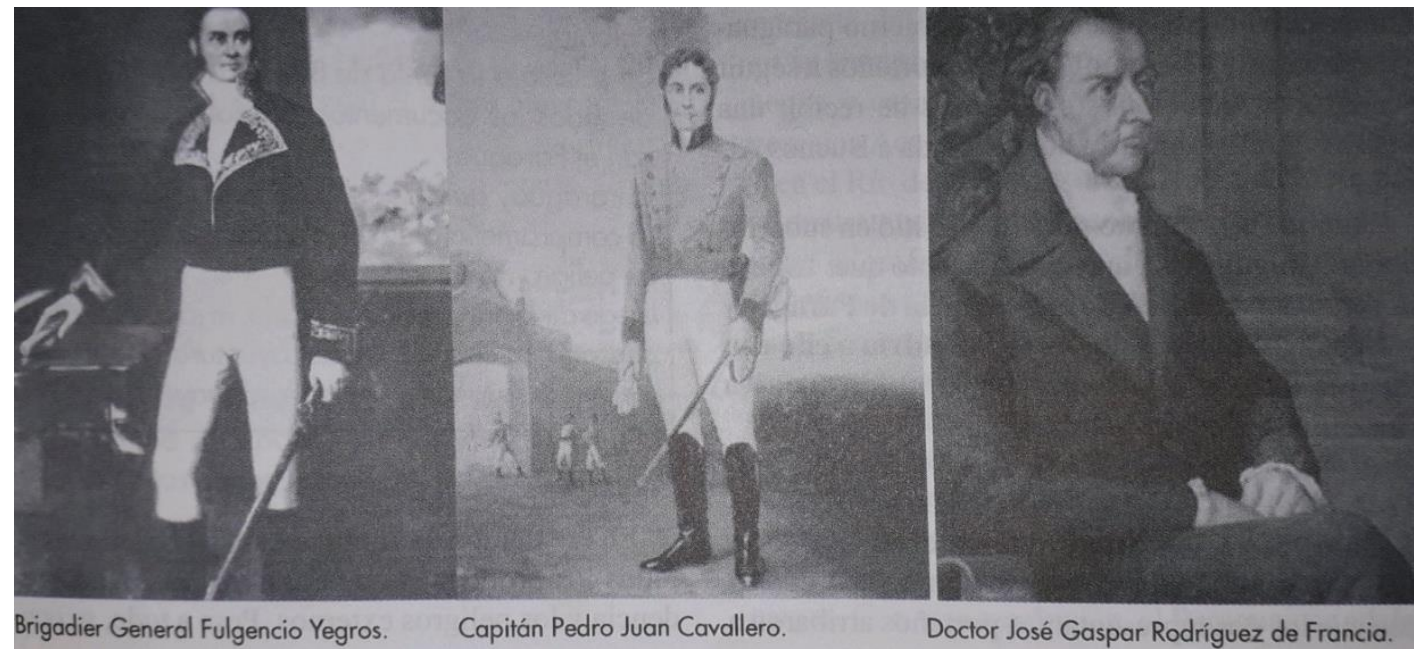

Fonte: MOREIRA, ROMERO, DÁVALOS, 2005: 119

Normalmente encontra-se presentes muitas imagens em manuais didáticos principalmente as figuras ilustres de próceres de independência. Na imagem acima (figura 02), observa-se os três próceres da independência que mais se destacam no manual da $8^{\circ}$ série de 2005, da esquerda para a direita: Fulgencio Yegros, Pedro Juan Cavallero e José Gaspar Rodriguez de Francia.

Na figura 02, Francia é representado com os cabelos pretos, semblante de homem formado, mas ainda jovial, diferente de outros períodos, dependendo da fase de governo sua imagem é representada de outra maneira, as vezes mais jovem com cabelo preto, as vezes mais velho com cabelo branco a fim de criar ou atender ao imaginário do púbico alvo dos materiais didáticos.

O segundo manual analisado é sobre o conteúdo de história e geografia do $2^{\circ}$ ano do ensino médio, produzido em 2017 e distribuído pelo MEC. Por ser direcionado ao ensino médio, esse manual apresenta uma narrativa mais abrangente sobre o governo de Francia problematizando variados aspectos, mas mantendo a ênfase para a exaltação da figura de Francia. Contém um número maior de imagens que retratam os próceres da independência. A estrutura não é diferente daquele presente no primeiro manual. $\mathrm{O}$ encadeamento da narrativa atribui destaque para as imagens de Francia e sua jornada no governo.

Logo no início da unidade, no capítulo 8, a imagem de Francia é destacada, apresentando tanto para o professor como o aluno que o tema a ser tratado nesse capítulo será o governo de 
José Gaspar Rodríguez de Francia. Como é início do capítulo, as narrativas começam com os primeiros eventos destacando sobre os primeiros governos independentes.

Figura - 3: Governo de doutor José Gaspar Rodriguez de Francia

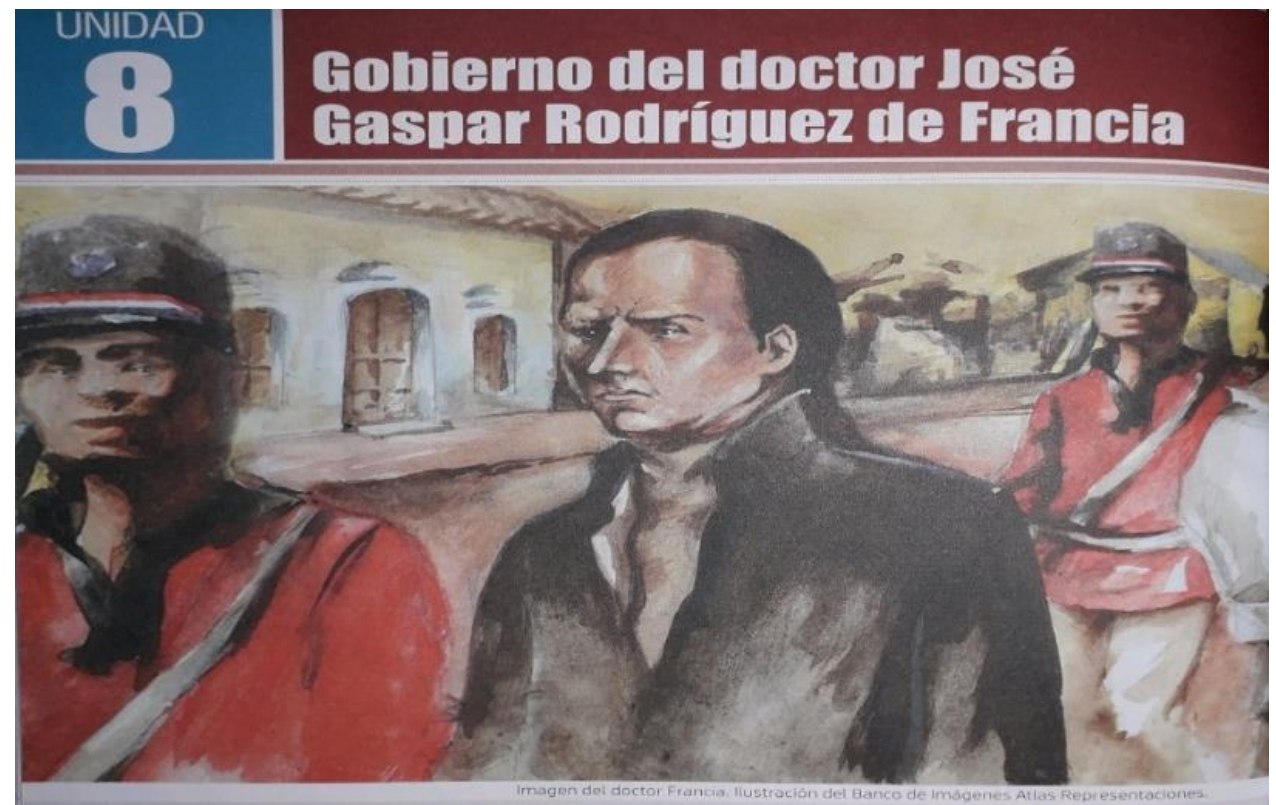

Fonte: Ilustración del Banco de Imágenes Atlas Representaciones. (EQUIPO EDITORIAL, HISTÓRIA Y GEOGRAFIA, 2017: 80)

A imagem (figura 03) quer apresentar um Francia popular, pessoa simples, do povo, andando pelas ruas, um estilo jovial, de cabelos pretos associado ao começo da vida política, o título deixa claro que será tratado neste capítulo sobre o governo de Francia.

Figura - 4: José Gaspar Rodriguez de Francia. 


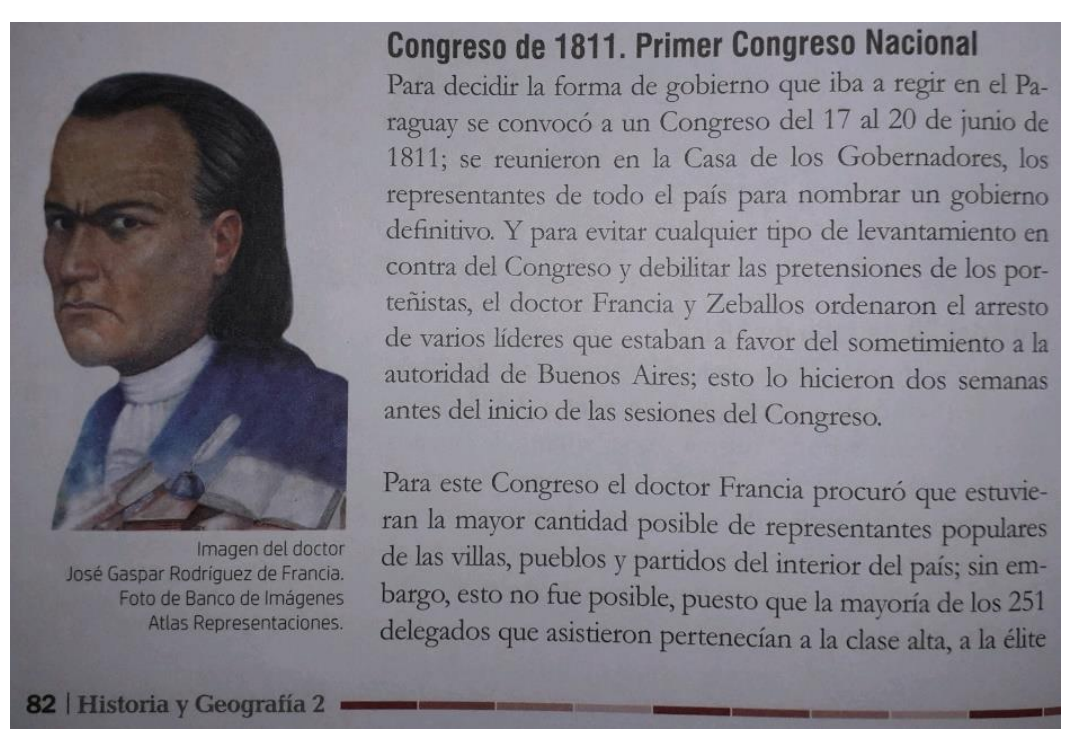

Fonte: Foto de Banco de imagens Atlas Representacional. (EQUIPO EDITORIAL, HISTÓRIA Y GEOGRAFIA, 2017: 82)

Como exposto (figura 4), Francia aparece com o semblante sério, franzido e de cabelos pretos, ao lado enunciado de um tema, 'Congreso de 1811. Primer Congreso Nacional', um dos eventos logo no início da trajetória política de Francia.

Figura - 5: Imagem de Pedro Juan Cavallero, Fulgencio Yegros e José Gaspar Rodriguez de Francia. Museu Casa da Independência.

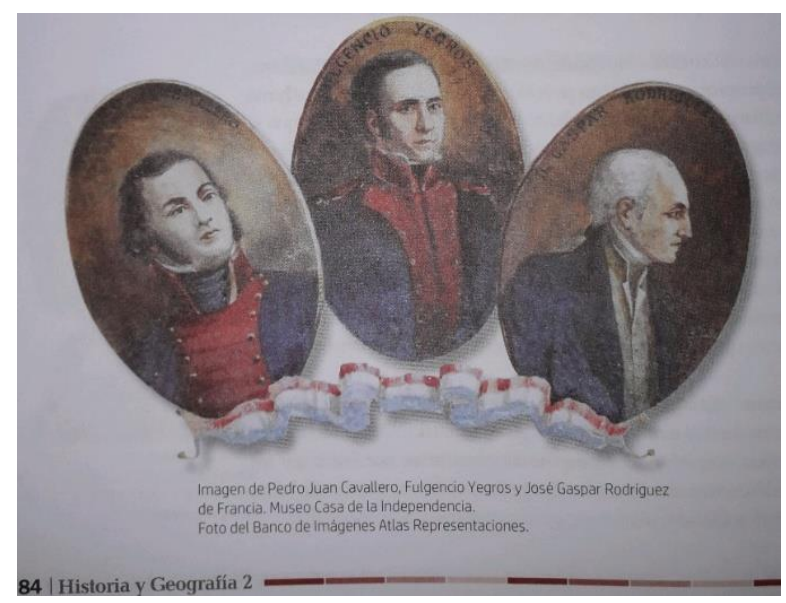

Fonte: Museo Casa de la Independencia. Foto del Banco de Imágenes Atlas Representaciones (EQUIPO EDITORIAL, HISTÓRIA Y GEOGRAFIA, 2017: 84).

A imagem acima (figura 05) apresenta os três próceres que mais se destacam no manual didático. Francia aparece muito mais nas narrativas historiográficas como também a sua imagem. Na imagem acima o primeiro a esquerda é Pedro Juan Cavallero, no meio Fulgencio 
Yegros e na direita Francia, porém retratado agora de cabelos brancos, aparentando um Francia mais maduro.

Imagem - 6: Imagem de Francia Panteão Nacional dos Heróis.

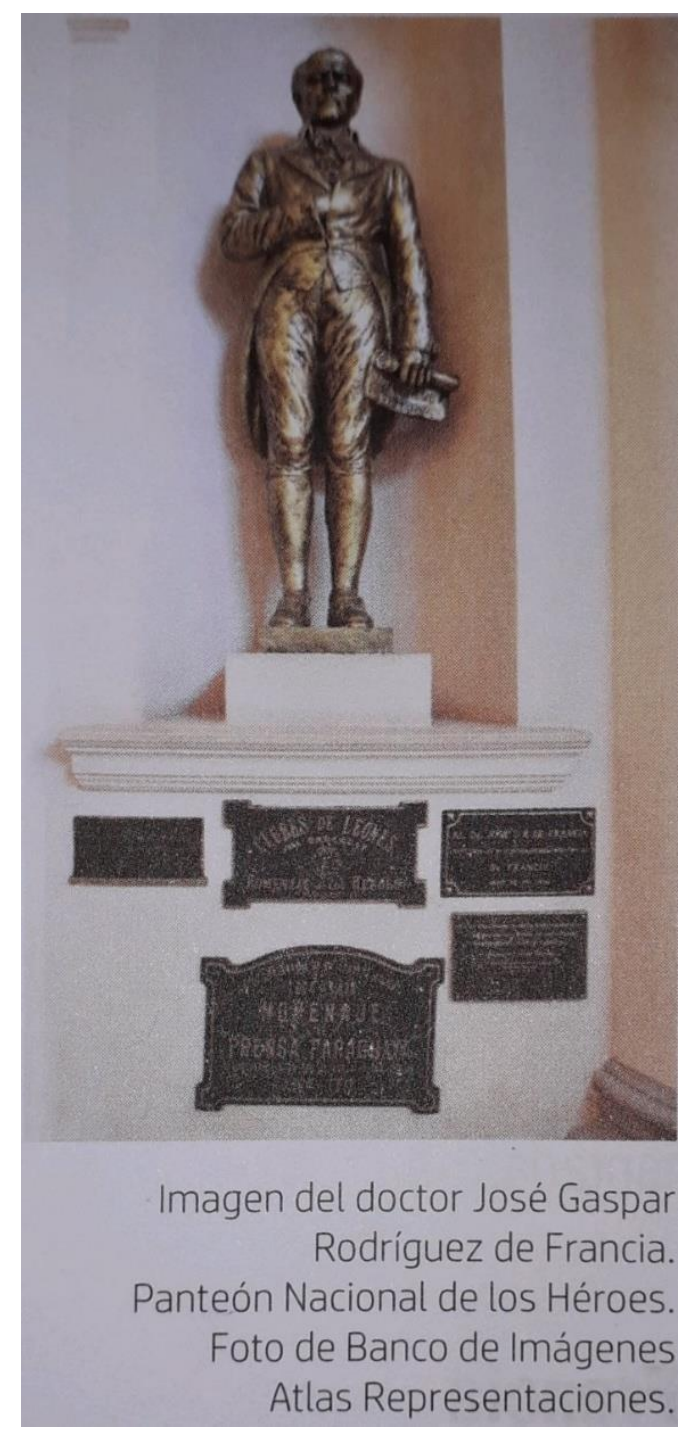

Fonte: Foto de Banco de imágenes Atlas Representaciones (EQUIPO EDITORIAL, HISTÓRIA Y GEOGRAFIA, 2017: 92)

Na imagem acima (figura 6) Francia se encontra no Panteão Nacional dos Heróis, espaço que começou a ser construído como templo católico no século XIX desde o período de Solano Lopez, tendo sido terminado somente no século XX, onde hoje se encontra-se também os restos mortais de Carlos Antônio Lopez e Solano Lopez, espaço de preservação das memórias de culto aos heróis da pátria.

No manual de história e geografia do ensino médio do $2^{\circ}$ ano de escola privada confeccionado no ano de 2016 nota-se que a estrutura não muda muito. Da mesma forma que 
os manuais das escolas públicas, este se concentra nas narrativas cronológicas, linear, com uso de imagens e textos associado as atividades em sequência.

Figura - 7: No primeiro quadro de imagens abaixo (07), retrata o período denominado de Triunvirato, caracterizado como um governo provisório logo no início, formado por Dr Francia de cabelos escuro na imagem à esquerda, no meio o ex-governador Bernardo de Velazco, e a direita Juan Valeriano Zevalhos.

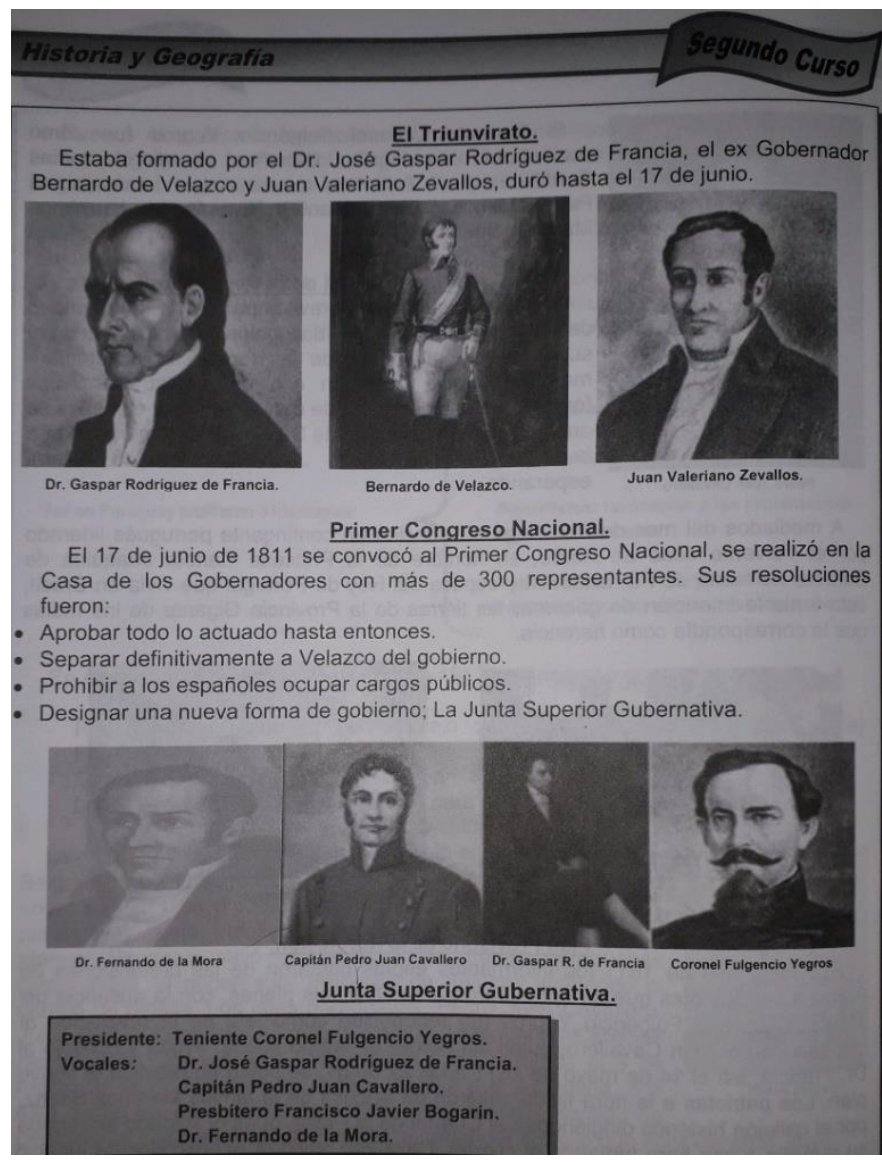

Fonte: IBÁNEZ, 2016: 40.

A imagens (figura 07) está relacionada com a formação do quadro político que ocorreu a partir do Primeiro Congresso Nacional em 17 de junho de 1811, nesse Congresso foi estabelecido algumas mudanças como a saída definitiva do ex-governador Velazco do governo e a designação de uma nova forma de governo a qual ficou denominada de Junta Superior Governativa.

A Junta foi formada então por Dr. Fernando de La Mora a esquerda o qual seria destituído do governo mais adiante por Francia, o Capitão Pedro Juan Cavallero, o qual seria preso por conspiração a partir de 1820, morreria na prisão tirando sua própria vida, Dr. José Gaspar Rodríguez de Francia também na imagem representado com cabelos pretos, referência ao início de sua jornada na política, e o Tenente Coronel Fulgencio Yegros o qual ficou a cargo 
a Presidência da Junta, mais tarde viria ser também acusado de conspiração em 1820 sendo então fuzilado.

O manual de história e geografia do $3^{\circ}$ ano do ensino médio confeccionado no ano de 2010 de escola privada, na sua estrutura se aproxima do anterior com imagens, textos e atividades, são confeccionados pela mesma autora e editora, apenas os conteúdos, que variam, lembrando que são voltados para turmas de anos diferentes.

Contudo nesse do $3^{\circ}$ ano, no capítulo um, onde trata sobre a temática "Liberalismo e Nacionalismo", a imagem de Francia está totalmente relacionada ao Nacionalismo no Paraguai, e o que chama atenção é a imagem do General Alfredo Stroessner (ditador paraguaio de 19541989) ao lado da sua, além das páginas sequenciais do capítulo trazerem outras personalidades, intelectuais e históricas que apoiaram o nacionalismo paraguaio.

$\mathrm{Na}$ imagem abaixo (Figura 8), o texto traz uma narrativa a qual associa a presença do sentimento nacionalista ao longo da história paraguaia, ideias libertárias, nacionalistas que estiveram em voga principalmente durante os eventos da Guerra contra a Tríplice Aliança e a Guerra do Chaco.

Figura - 8: Nacionalismo paraguaio: Francia e Stroessner dividem a mesma página da história

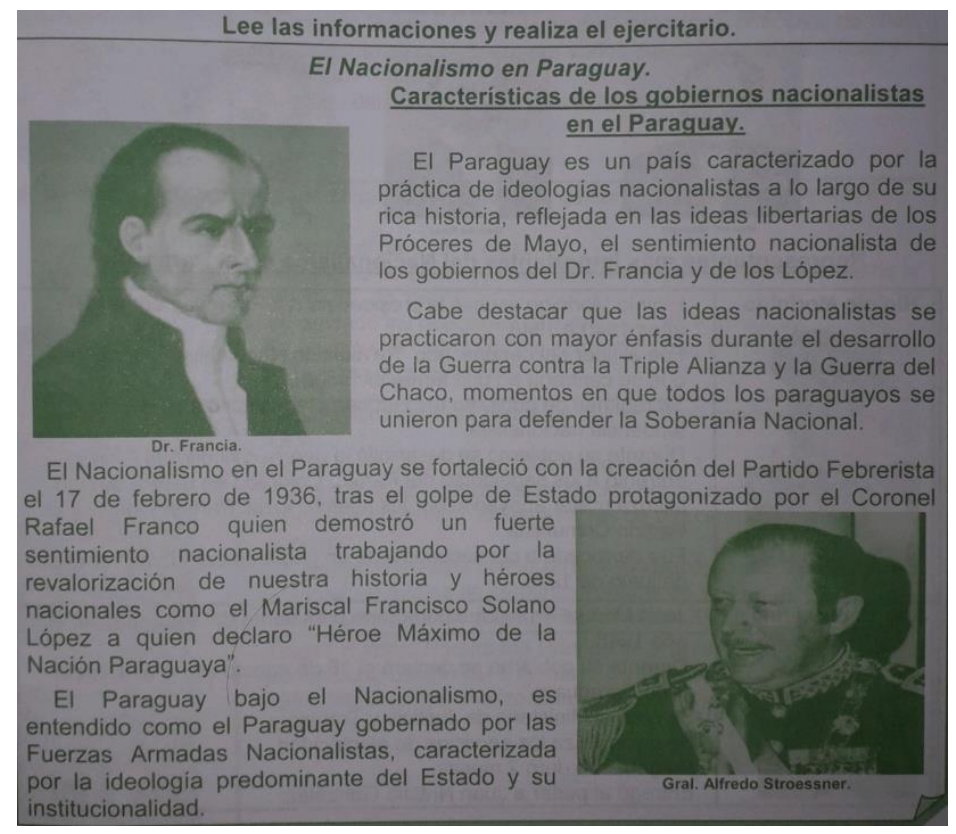

Fonte: IBÁNEZ, 2010: 25.

Observa-se a partir das narrativas historiográficas que o sentimento nacionalista associado a ideia de Nação e defesa de um território artificialmente concebido, esteve presente nos processos de independência do Paraguai representado pela imagem de Francia nos manuais didáticos, como nos eventos da guerra contra a Tríplice Aliança que remete a Lopez, e a do 
Chaco contra a Bolívia. Na imagem acima (Figura 08) vemos uma associação entre a imagem de Francia e Alfredo Stroessner relacionada ao nacionalismo onde se associa aos militares, por mais negativo que uma ditadura seja, o nacionalismo está imbuído no contexto como algo bom que se relaciona a nação, sendo atribuído as instituições militares e seus representantes.

Entretanto observa-se que após os eventos da guerra contra a Tríplice aliança, ocorreu algumas mudanças no modo de pensar e olhar para esse passado, ocasionado com a restruturação de uma nova política e a influência investida pelos vencedores da guerra. Somouse a esses eventos um movimento posteriormente por parte de autores liberais, movimento de deslegitimação dos governos anteriores principalmente de figuras como Dr. Francia, Antonio Lopez e Solano Lopez, encabeçado principalmente pelo intelectual Cecílio Baez (1862-1941), entre outros que formavam a geração que ficou conhecida como a geração de "Novecentos" $(900)^{\text {vii }}$. Segundo Lima (2018), o governo de Francia e os Lopez foram caracterizados como governos “decimonónicos"viii.

\section{Sendo assim, Solano López também era apontado como o responsável pelo conflito e por suas consequências devastadoras. Tais desvirtuamentos também se estendiam aos demais governos decimonónicos, de Gaspar Rodríguez de Francia e Carlos Antonio López, por razão da centralização dos poderes estatais e a condição de isolamento político e econômico que teriam caracterizado seus governos. (LIMA, 2018: 21).}

Em contrapartida em resposta aos ataques de liberais como Cecílio Baez (1862-1941), que criticavam e caracterizavam os governos anteriores como "dicimonónicos", a defesa do nacionalismo e atribuição aos feitos dos governos antepassados, ficou a cargo do então também intelectual Juan Emilio de O’Leary (1879-1965), colorado, que também fazia parte da geração "novecentista".

Segundo Lima (2018), o resultado desses embates entre estes intelectuais teria ficado favorável para O’Leary (1879-1965), que buscava reconstruir esse passado com suas narrativas, e de certa forma confortava seus leitores, pois a sociedade buscava se recuperar ainda do trauma da guerra no começo do século XX, procuravam olhar para este passado como um período glorioso, comparando como uma idade de ouro, de bem estar, de bonança, e riqueza, pois ao contrário segundo suas concepções, teria sido seus vizinhos os vencedores que os colocaram em tal situação que se encontravam.

\section{Considerações finais}


A história e o ofício do historiador são relevantes nos registros das memórias das sociedades ao longo do tempo e espaço. Nesse sentido, o uso da história também contribui para edificação de sentimentos de identidades nacionais, de pertencimento, de culto a "heróis", que são edificados ao longo do tempo. Este processo inclui também a produção de esquecimentos, e depende da abordagem do historiador, do período, dos fatos, das memórias, das instituições e espaços de poder.

As narrativas cronológicas, lineares presentes nos manuais didáticos aqui tratados influenciam na formação, preservação e construção das identidades sociais nos espaços escolares. A escola tem na sua origem a função de moldar os alunos desde tenra idade de acordo com programas e políticas educacionais aliado ao currículo, os quais são confeccionados de tempos em tempos e que sofrem influência daqueles que se encontram nos espaços de poder de uma nação e suas instituições.

Nota-se que as narrativas cronológicas/lineares dos manuais didáticos públicos e privados e as narrativas apresentadas marcaram o período da independência paraguaia, com destaque para a imagem de Francia em silenciamento aos processos, ênfase também para datas e fatos relacionados aos períodos de governo, enaltecendo também o nacionalismo. A história sobre o processo de independência nos manuais didáticos, carrega um significado maior, porque nas sociedades contemporâneos a independência é caracterizada como o nascimento da Nação. Ela inaugura o sentimento de próprio, do específico, mesmo que populações latino-americanas foram sacrificadas em nome da independência, o sentido de Nação tem ocupado um espaço consideravelmente maior nos manuais didáticos. Na criação na Nação paraguaia os indígenas não aparecem no processo, como se eles não existissem no Paraguai oitocentista.

Concluímos, portanto, que a escola, currículo e os manuais didáticos não são neutros, e no caso em especial reproduzem e exaltam uma certa harmonia, justificando que a eliminação da oposição era justa e necessária para engrandecimento da pátria. Francia passa a ser o exemplo do herói a ser seguido, da referência de patriotismo e entrega total em nome do povo. Os manuais praticamente não abrem espaços para novas interpretações, problematizações, com abordagens críticas e reflexivas que proporcione aos alunos a refletirem e pensarem, educando sujeitos críticos/reflexivos, atuantes e não passivos, que se moldam pelo sistema. É como se o manual alertasse: 'a história já vem pronta, não ousem mudar'. 


\section{Referências}

APPLE, Michael W. Ideologia e currículo. tradução Vinicius Figueira. - 3 ed. - Porto Alegre: Artmed, 2006.

AVILA, Salonides José Zanella de. O mundo do trabalho e educação. [S.1.], [2016-1018]. Disponível em: <http://www.gestaoescolar.diaadia.pr.gov.br/>. Acesso em: 24 nov. 2019.

FRUTOS, Julio César. Actas del cabildo de la asunción (1822-1824). Biblioteca del Bicentenario: $1^{\text {o }}$ edición Servilibro, Asunción, 2009.

CARRERAS, Sandra. “Del »Reino Del Terror« Al »Modelo De Desarrollo Autocentrado«.: Las Diferentes Interpretaciones Acerca De La Figura Histórica Del Dictador Supremo Del Paraguay, Dr. José Gaspar Rodríguez De Francia.” Iberoamericana (1977-2000), vol. 16, no. 1 (45), 1992, pp. 17-35. JSTOR. Disponível em: 〈www.jstor.org/stable/41671293〉. Acesso em: 24 mar. 2021

CHARTIER, Roger. Defesa e ilustração da noção de representação. Fronteiras. Dourados, MS, v. 13, n. 23, jan./jun. 2011.

CHARTIER, Roger. Rappresentazione della Pratica, Pratica della Rappresentazione. Quaderni Storici. n. 92, ano XXXI, n. 2, p. 487-493, 1996.

CHAVES, Julio César. Compendio de Historia Paraguaya. Intercontinental Editora: Asunción, 2010.

CARDOSO, Ciro Flamarion. Apresentação. In: CARDOSO, Ciro Flamarion; VAINFAS, Ronaldo. (Org.) Novos domínios da história. Rio de Janeiro: Elsevier, 2012.

CHOPPIN, Alain. História dos livros e das edições didáticas: sobre o estado da arte. Educ. Pesqui. vol.30 nº.3 - São Paulo Set./dez. - 2004.

GOODSON, Ivor F. A Construção Social do Currículo. (Educa Currículo), Lisboa: 1997. Equipo Editorial. - Asunción: Editorial Atlas, 2017.

EQUIPO EDIOTIAL. história y geografia. Segundo Curso. - Equipo Editorial. - Asunción: Editorial Atlas, 2017.

MOREIRA, Antonio Flavio Barbosa, Currículo, Utopia e Pós Modernidade - In: (org)___ Currículo: Questões atuais. Coleção Magistério. Formação e Trabalho pedagógicos. Campinas, SP: Papirus, 1997.

IBÁNEZ, Felisa. Historia y Geografía. Recursos Facilitadores de Enseñanza - Aprendizaje, Con Capacidades, Indicadores y Test de Evaluación. Editora Book Sellers. Nemby Paraguay. 2010. 
IBÁNEZ, Felisa. História y Geografia. Recursos Facilitadores de Enseñanza - Aprendizaje, Con Capacidades, Indicadores y Test de Evaluación. Editora Book Sellers. Nemby Paraguay. 2016.

LIMA, Leticia Consalter de. Stroessner: biografía, história e propaganda, 1972-1979/. Dissertação (Mestrado em Programa de Pós-Graduação Interdisciplinar em Estudos LatinoAmericanos) - Universidade Federal da Intergração Latino Américana - UNILA. Foz do Iguaçu, Pr. 2018.

MOREIRA, María Graciela Monte de Lopez, ROMERO, Ana Carolina Reyes, DÁVALOS, Juana. Historia y Geografía. 8 $^{\circ}$. Ministerio de Educación y Cultura - MEC, Viceministerio de Educación. Editorial Don Bosco: Asunción, 2005.

RÜSEN, Jörn. El libro de texto ideal. Reflexiones en torno a los medios para guiar las clases de historia. Iber: Didáctica de las ciencias sociales. geografía e historia, v. 4, n. 12, p. 79-93, abril, 1997.

SKINNER, Quentin. Lenguage, Política e Historia/ Quentin Skinner; con prólogo de: Eduardo Rinsesi - Ia e.d. - Bernal: Univ. Nacional de Quilmes, 2007.

SANTOS, Dominique Vieira Coelho dos. Acerca do Conceito de Representação. Revista de Teoria da História. Ano 3, Número 6, dez/2011.

\footnotetext{
i “O livro didático é então apenas a fiel tradução do programa [...] ele constitui o suporte privilegiado dos conteúdos educativos, o depositário dos conhecimentos, técnicas ou habilidades que um grupo social acredita que seja necessário transmitir às novas gerações. (CHOPPIN, 2004: n.p.).

ii “O livro didático põe em prática métodos de aprendizagem, propõe exercícios ou atividades que, segundo o contexto, visam a facilitar a memorização dos conhecimentos, favorecer a aquisição de competências disciplinares ou transversais, a apropriação de habilidades, de métodos de análise ou de resolução de problemas, etc." (CHOPPIN, 2004: n.p.).

iii "É a função mais antiga. A partir do século XIX, com a constituição dos estados nacionais e com o desenvolvimento, nesse contexto, dos principais sistemas educativos, o livro didático se afirmou como um dos vetores essenciais da língua, da cultura e dos valores das classes dirigentes. Instrumento privilegiado de construção de identidade, geralmente ele é reconhecido, assim como a moeda e a bandeira, como um símbolo da soberania nacional e, nesse sentido, assume um importante papel político. Essa função, que tende a aculturar - e, em certos casos, a doutrinar - as jovens gerações, pode se exercer de maneira explícita, até mesmo sistemática e ostensiva, ou, ainda, de maneira dissimulada, sub-reptícia, implícita, mas não menos eficaz". (CHOPPIN, 2004: n.p.).

iv "Acredita-se que o livro didático pode fornecer, sem que sua leitura seja dirigida, um conjunto de documentos, textuais ou icônicos, cuja observação ou confrontação podem vir a desenvolver o espírito crítico do aluno. Essa função surgiu muito recentemente na literatura escolar e não é universal: só é encontrada [ ] afirmação que pode ser feita com muitas reservas [ ] em ambientes pedagógicos que privilegiam a iniciativa pessoal da criança e visam a favorecer sua autonomia; supõe, também, um nível de formação elevado dos professores". (CHOPPIN, 2004: n.p.).

${ }^{v}$ Vocales: pessoa que tem voz em uma junta ou conselho.

vi “Cabildo tanto quiere decir en latín como ayuntamiento de hombres dicen las Partidas, y ciertamente es el cuerpo colegiado que delibera sobre los intereses de las comunidades, distribuye justicia al vecindario y ejerce el gobierno del municipio." (GONZÁLEZ apud FRUTOS, (2009: 10).

vii Os novecentistas, denominação pelo qual também ficou conhecida esta geração, compreende os nascidos entre 1870 e 1880. Sendo que suas atuações nos campos cultural e intelectual se concretizaram a partir da década de 1900. (LIMA, 2018, p. 22).

viii Dicionário infopédia - 1- oitocentista, do século XIX / 2. pejorativo antiquado fora de moda.
} 